\title{
The mangrove forests as nursery habitats for the ichthyofauna of Mida Creek (Kenya, East Africa)
}

\author{
LAURA GAJDZIK ${ }^{1,2,3}$, ANN VANREUSEL ${ }^{1}$, NICO KOEDAM ${ }^{2}$, JAN REUBENS ${ }^{1}$ \\ AND AGNES WANGUI N. MUTHUMBI ${ }^{4}$ \\ ${ }^{1}$ Marine Biology Research Group, Biology Department, University of Ghent, Krijgslaan 281, S8, B-90oo Gent, Belgium, ${ }^{2}$ Laboratory \\ for Plant Biology and Nature Management, Free University of Brussel, Pleinlaan 2, B-1050 Brussel, Belgium, ${ }^{3}$ Present address: \\ Laboratory of Functional and Evolutionary Morphology, University of Liège, Allée de la chimie 3, B6c, B-40oo Liège, Belgium, \\ ${ }^{4}$ School of Biological Science, University of Nairobi, PO Box 30197-00100, Nairobi, Kenya
}

\begin{abstract}
This study investigated the presumed nursery function of mangroves for the ichthyofauna in East African swamp forests, Mida Creek. The species and size composition of the fish fauna and their trophic interactions were studied for five stations. Samples were collected during 5-6 consecutive days close to spring tide in mid-July 2011. Fish were caught using different types of passive fishing gear, such as large and small fyke nets, gill nets and, additionally, beach seines. All individuals were identified to species level, measured and preserved for further analyses. Stomach content analysis was applied to provide information about their diet. Stable isotope analysis was used to detect whether the source of primary production for the higher trophic levels is mangrove-related or not. A total of 27 fish species was recorded in a catch of 938 teleost specimens. Our analyses showed that a majority of fish belonged to the zoobenthivorous/omnivorous trophic mode, since they were partially feeding on invertebrates and on various other food sources. Two species (Sphyraena barracuda and Synodus variegatus) exhibited a mixed diet, with a piscivorous preference. Results concerning the population structure suggested that the fish community of Mida mainly consists of transient species. Juveniles were numerically more abundant in the whole Creek than adults. These findings support the hypothesis of a nursery function of the mangrove forests, Mida Creek.
\end{abstract}

Keywords: Kenya, Mida Creek, mangroves, ichthyofauna, stable isotopes, nursery habitat

Submitted 21 October 2013; accepted 3 February 2014; first published online 18 March 2014

\section{INTRODUCTION}

Mangroves are defined as forests consisting of trees, palms, shrubs, vines and ferns that occupy the inter-tidal region between sea and land throughout (sub)-tropical regions (Polidoro et al., 2010; Giri et al., 2011). Mangrove trees are the major, highly specialized components of these ecosystems and attract a rich associated fauna and flora (Tomlinson, 1986). Like many other forests in the world, the coverage of mangroves is decreasing: $20-35 \%$ of mangrove forest area has been lost worldwide since 1980 (Valiela et al., 2001). This decrease is largely due to deforestation and degradation by human activities (e.g. urban development, aquaculture or salt extraction) (Ewel et al., 1998; Abuodha \& Kairo, 2001; Rönnbäck et al., 2007). Given the high anthropogenic pressure on mangrove ecosystems, understanding their roles is of crucial importance for future management.

Mangroves are part of the 'tropical coastal seascape' comprising coral reefs, seagrass beds and mud/sand flats (Moberg \& Rönnbäck, 2003). The connectivity between mangrove forests and the adjacent ecosystems for the ichthyofauna

Corresponding author:

L. Gajdzik

Email: l.gajdzik@student.ulg.ac.be has already been elucidated by several studies and evidence from the overlaps in carbon and nitrogen signatures of fish collected in these different environments (Nagelkerken et al., 2012; Igulu et al., 2013; Kimirei et al., 2013). These isotopic signatures suggest that juvenile and/or adult fish probably choose more than one habitat to feed, find shelter or both (Lugendo et al., 2006, 2007). Their movements may be triggered by several factors: tides, food availability, variation in salinity and/or ontogeny (Cocheret de la Morinière et al., 2003; Lugendo et al., 2005, 2006; Nakamura et al., 2008; Kimirei et al., 2013). Mangroves may, therefore, be designated as potential nurseries for pelagic and demersal coral reef fish and crustaceans (Laegdsgaard \& Johnson, 2001; Nagelkerken et al., 2002; Nagelkerken, 2009). A 'nursery' is defined as a habitat for immature fish where density, growth, survival of juveniles and movement to adult habitats are enhanced compared to adjacent habitats (Beck et al., 2001; Dahlgren et al., 2006). According to that definition, three hypotheses emerge to explain the attractiveness of the mangrove environment (Sheridan \& Hays, 2003):

1. A mangrove environment supports greater food availability allowing a faster growth or greater population survival rates (Lugendo et al., 2007; Nagelkerken, 2009).

2. The turbid waters in mangroves lower the effectiveness of predators (Primavera, 1997). 
3. The heterogeneity of mangrove sub-habitats (e.g. root complex) leads to a decreased rate of predation (Nagelkerken et al., 2008; Nagelkerken, 2009).

All these hypotheses have not really been tested, but evidence suggests that the presence of roots appears to be one of the most important criteria in attracting fish larvae (Nagelkerken et al., 2010). Concerning food availability, the potential proliferation of both primary producers and secondary consumers on the substratum may be essential in the diet of fish. In fact, the muddy or sandy sediments are colonized by epibenthic and infaunal invertebrates which represent suitable prey (Lugendo et al., 2007; Nagelkerken, 2009). This concept of nursery function has been illustrated by Laegdsgaard (1996) in Australia and experimentally described by Kimirei et al. (2013) in Tanzania, but still needs to be tested in mangrove ecosystems of the Kenyan coast. Indeed, most Kenyan ecological studies have been focused on identifying the fish composition and diversity of mangrove forests, fish diets and trophic interactions. All of these researches partially tackled one or two aspects of the nursery concept, either the feeding function and/or the role of shelter. In addition, Kenyan studies have mainly been conducted in swamp forests located in the south (e.g. Gazi Bay, Tudor Creek and Mtwapa Creek) (Kimani et al., 1996; De Troch et al., 1996, 1998; Wakwabi, 1999; Wakwabi \& Mees, 1999; Huxham et al., 2004; Mavuti et al., 2004; Nyunja et al., 2009), and only one major study has been performed in the mangroves of Ungwana Bay on the north coast (Mirera et al., 2010).

The present study aims at identifying the fish assemblage of Mida Creek, and the functions provided by mangroves to the ichthyofauna. Three main objectives were identified:

(1) To describe the fish assemblage.

(2) To determine the population structure of the ichthyofauna.

(3) To unravel the trophic interactions within the mangrove system using stable isotopes and stomach content analysis.

\section{MATERIALS AND METHODS}

\section{Description of the study area}

Mida Creek $\left(3^{\circ} 22^{\prime} \mathrm{S} 39^{\circ} 58^{\prime} \mathrm{E}\right)$ is located $88 \mathrm{~km}$ north of Mombasa and approximately $25 \mathrm{~km}$ south of Malindi (Kairo \& Bosire, 2009) (Figure 1). The area is covered by $32 \mathrm{~km}^{2}$ of mangroves which border several villages such as Majaoni, Uyombo and Dabaso. Two dominant tree species in the whole area are Rhizophora mucronata and Ceriops tagal (Kairo et al., 2002; Kathiresan \& Rajendran, 2005). The Creek consists of a channel $11 \mathrm{~km}$ long which is narrower at the mouth and further inland (width $500 \mathrm{~m}$ ), while it is wider in the middle part $(1500-2000 \mathrm{~m})$. The depth varies between $4 \mathrm{~m}$ and $7 \mathrm{~m}$ maximum (Osore et al., 2004). The climate is dominated by the monsoon, and the rainfall delivers annually a quantity of $600-1000 \mathrm{~mm}$ of freshwater (GOK, 1989; Mwaluma et al., 2003). In May, there is the highest rate of precipitation of about $760 \mathrm{~mm}$, with a typical rainy season extending from May to September. The tidal range is about $3.2 \mathrm{~m}$ at the mouth of the Creek and $2.0 \mathrm{~m}$ in the mid-section (Mwaluma et al., 2003). Lower temperatures are recorded in JulyOctober, with an average of $24^{\circ} \mathrm{C}$, and the highest in November-March, with an average of $32^{\circ} \mathrm{C}$ (Osore et al., 2004).

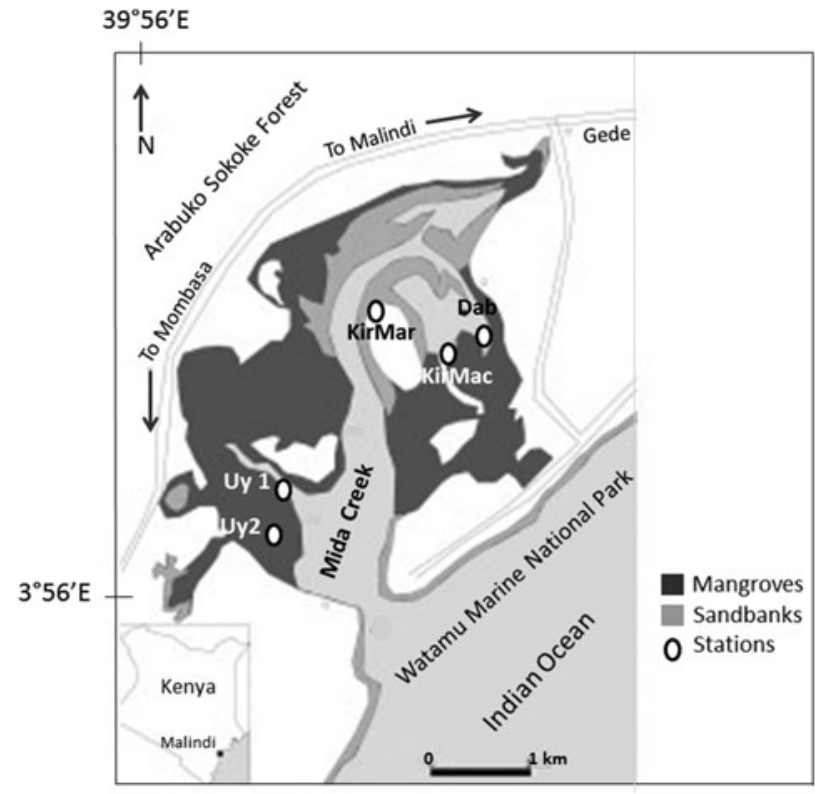

Fig. 1. Map of Mida Creek, adapted from Osore et al. (2004), with all five stations indicated: Uy1 (Uyombo 1); Uy2 (Uyombo 2); KirMar (Kirepwe Mark); KirMac (Kirepwe Macho); and Dab (Dabaso).

Mida Creek is part of Watamu Marine National Reserve. This area, which comprises a mangrove forest, sandflats, rock platforms, seagrass beds and coral gardens, received the status of a UNESCO Biosphere Reserve in 1979 (Kennedy, 1988; Dahdouh-Guebas et al., 2000). Biosphere reserves are considered as sites of excellence where optimal techniques to manage nature and human activities are tested and demonstrated (http://www.unesco.org/new/en/naturalsciences/environment/ecological-sciences/biosphere-reserves/). Therefore, limited human activities are allowed, but their impacts on the flora and fauna in Mida Creek needs to be ascertained. A main issue that requires further attention is the knock-on effect within the ecosystem of overfishing and exploitation of the marine environment, as stated in Jackson (2010). In the past, local human populations have frequently exploited mangroves (e.g. harvesting wood) (Jackson, 2010). Given the indigenous rights and property ownership, conflicting issues with authorities have emerged (Taylor et al., 2003). However, local initiatives to conserve and implement sustainable management of the natural resources have been successfully launched by the Mida Creek Conservation Community Group.

Across the mangroves, five stations were selected at Mida Creek (Figure 1). These stations represented different environmental conditions, and were considered to be representative for some of the variability in the area. At the entrance of the main channel of Mida Creek (near Sudi Island), station Uyombo 1 was chosen because of its situation deep in the mangrove forest where permanent pools are formed. Uyombo 2 station was situated at the border of swamp forests, closer to the village and potentially more disturbed by human activities. Around Kirepwe Island, sampling sites within the mangrove forests offered a connection with other valuable ecosystems. Station Kirepwe Mark was situated in front of sand banks and seagrass beds, while station Kirepwe Macho was located on a large muddy area. The last station selected was Dabaso at the end of the mangrove 
Creek within the wider village infrastructure and so potentially more disturbed by anthropogenic activities.

\section{Sampling}

Sample collections were carried out in July 2011 at the five stations in Mida Creek (Uyombo 1, Uyombo 2, Kirepwe Mark, Kirepwe Macho and Dabaso). This campaign was conducted during a spring tide, when a tidal range of $3.0-3.6 \mathrm{~m}$ was prevailing, for a period of 5-6 consecutive days. All types of passive fishing gears were set during low tide (in the morning) and retrieved after $24 \mathrm{~h}$ (after dawn, before the incoming spring tide), except for Kirepwe Mark. At that station fish were caught using a beach seine (mesh size $2.54 \mathrm{~cm}$ ) because all other nets (removed after $24 \mathrm{~h}$ ) were empty. The passive fishing gears consisted of three large and four small fyke nets, for which mesh sizes were, respectively, $15 \mathrm{~mm}$ and $5 \mathrm{~mm}$ with an outer cone of $30 \mathrm{~mm}$ and an inner cone of $15 \mathrm{~mm}$. The nets were always placed at the entrance of the main water channel at each station, in front of the mangrove border, and also in smaller channels present inside the mangrove forest. Four gill nets (mesh sizes: $2.54 \mathrm{~cm}, 3.81 \mathrm{~cm}, 5.08 \mathrm{~cm}$ and $6.35 \mathrm{~cm}$ ) were additionally placed to catch more fish in the permanent pools. Fish were, therefore, caught after two tidal cycles $(24 \mathrm{~h})$ per station. In the field, they were placed on ice and preserved in a coolbox. Fish specimens were measured (standard length (SL) = the distance from the tip of the mouth to the basis of the caudal fin) and their stomachs were removed and preserved in a formaldehyde solution (8\%) for dissection. Tissue samples of lateral muscles of two or three specimens per species were collected and fixed into an ethanol solution (99\%) for stable isotope analysis. In the laboratory, all specimens were identified to species level according to Richmond (2002) and FishBase (Froese \& Pauly, 2011). Various primary producers (e.g. mangrove leaves, seagrass leaves, macroalgae, etc.) and some invertebrates (i.e. sponges and jellyfish) were, in an unselective manner, collected in some parts of the study area and preserved in formaldehyde (8\%) to investigate their isotopic signatures. There are no replicates available for all the potential food sources found in the mangrove environment.

\section{SAMPLE PROCESSING}

Stable isotopes analysis

All types of primary producers were treated according to the protocol described in Nyunja et al. (2009). Samples of each food item were thoroughly and carefully washed with milli- $q$ water two to three times. A small portion of each sample was placed on a pre-combusted Whatman GF/F filter with a pore-size of $0.7 \mathrm{~mm}$. Milli-q water was added to the filtration apparatus. Then the GF/F filters were transferred to Petri dishes and kept in a freezer at $-20^{\circ} \mathrm{C}$ for $24 \mathrm{~h}$. Then, these samples were freeze-dried for $3 \mathrm{~h}$. The acidification step for $50 \%$ of the samples was done by $\mathrm{HCl}$ fumes into $\mathrm{HCl}$ vacuum for $4 \mathrm{~h}$. The filters were also re-dried at $60^{\circ} \mathrm{C}$ for $24 \mathrm{~h}$ prior to analysis (Lorrain et al., 2003). For sponge and jellyfish tissues, a few drops of $\mathrm{HCl}(0.25 \mathrm{~N})$ were added to the silver cups, in which invertebrate tissues were put, in order to remove carbonates. Samples were re-dried on a preheated plate at $60-70^{\circ} \mathrm{C}$ (Nieuwenhuizen et al., 1994).

A total of 41 fish tissue samples were also thoroughly and carefully washed with milli-q water. Per species, three replicates from three different individuals (except for Platycephalus indicus, for which only two individuals were caught, and for Acentrogobius nebulosus and Leiognathus equulus, for which no samples were used as they were too degraded) were separately placed into pre-combusted glass Petri dishes to avoid any contamination. All samples were oven-dried at $60^{\circ} \mathrm{C}$ for $48 \mathrm{~h}$. The dry tissues were weighed according to sample type (0.5 mg for fish, $1.2 \mathrm{mg}$ for sponges and $1.0 \mathrm{mg}$ for jellyfish) and the appropriate amount of material was placed in silver cups (previously combusted at $450^{\circ} \mathrm{C}$ for $4 \mathrm{~h}$ ).

Samples of both food sources and fish tissues were analysed using a Flash Elemental Analyzer (EA) 1112 HT coupled through Conflo IV to Thermo Delta V Advantage Isotope Ratio Mass Spectrometer. Carbon and nitrogen isotope ratios were expressed in the conventional delta notation $\left(\delta^{13} \mathrm{C}, \delta^{15} \mathrm{~N}\right)$ relative to standard reference materials and the results from the formula:

$$
\delta X=[(\text { Rsample } / \text { Rstandard })-1] \times 1000
$$

where $\mathrm{X}$ is either ${ }^{13} \mathrm{C}$ or ${ }^{15} \mathrm{~N}$ and $\mathrm{R}$ is the ratio of the heavy to the light isotope (Nyunja et al., 2009).

Potential food sources were fixed with a formaldehyde solution and resulted in an average depletion of $1.65 \%$ of $\delta^{13} \mathrm{C}$ values (Sarakinos et al., 2002) in comparison with fish tissues which were preserved in ethanol. Our results for $\delta^{13} \mathrm{C}$ were, therefore, corrected with consideration of the depletion due to the use of formaldehyde. For each trophic transfer between a consumer and its diet, we assumed that $\delta^{13} \mathrm{C}$ values increase on average by $1.0 \%$ (Fry \& Ewel, 2003; Nyunja et al., 2009), whereas $\delta^{15} \mathrm{~N}$ is typically cited to increase by $3.4 \%$ (Nyunja et al., 2009). By taking into account the respective enrichments in carbon and nitrogen isotopes, it is possible to determine the food range values of the prey which were preyed upon by fish.

\section{Stomach content analysis}

The stomachs of individuals belonging to eight fish species of greatest length (on average more than $4 \mathrm{~cm}$ ) were opened and all dietary constituents were released in petri dishes (except for Lutjanus ehrenbergii, A. nebulosus, Archamia mozambiquensis, Atherinomorus lacunosus and Periophthalmus argentilineatus, for which samples were not well preserved). These contents were further microscopically investigated for their composition by means of binocular magnifiers. These food items were identified to the lowest taxonomic level possible according to Richmond (2002), but given the numerous taxonomic uncertainties, we restricted our identifications to classes and families. We were not able to apply the gravimetic method (Hyslop, 1980) reliably as the stomach contents of each individual were too digested and the remaining fish species were represented by either very small or very few individuals for which no stomach dissection was performed. So we used our data as a presence/absence matrix.

\section{Statistical analysis}

Differences in fish assemblages between stations using different fishing gears were tested by creating a non-multidimensional scale plot (nMDS) based on a Bray-Curtis similarity matrix of relative fish abundance in the software PRIMER, v.6.1.6 (Plymouth Routines in Multivariate 
Ecological Research Ltd, UK). After removal of two outliers (i.e. two gill nets that each gathered one specimen), no significant differences were found. Therefore, data of fish abundance have been pooled together in the analysis regardless of the type of nets.

In order to compare isotope ratios between the different fish species and the food, one-way ANOVA was performed using $\mathrm{R}$ with a lattice package (Deepayan, 2008; R Development Core Team, 2008). All assumptions were fulfilled (Shapiro test for normality and Levene test for homogeneity of variances). As ANOVA results revealed that significant differences were found $(P \leq 0.001)$, a Tukey post-hoc test was performed for pairwise comparisons between species.

Stomach content data were analysed using the PRIMER software. The stomach data of each fish individual were treated as units. These data were firstly transformed into presence/ absence values before creating a Bray-Curtis similarity matrix to quantify the compositional dissimilarity. Similarities among stomach content of each individual were tested by ANOSIM (analysis of similarity), using species as a grouping factor. A SIMPER (similarity percentage) method was used to determine which variables (i.e. food items) were mostly influencing fish species groups and leading to differences within and between these groups (Clarke \& Green, 1988; Clarke, 1993).

\section{RESULTS}

\section{Species composition of the fish assemblage in Mida Creek}

During our survey, 27 teleost species were encountered in Mida Creek with 16 species contributing each $<_{1} \%$ to the total catch of 938 specimens (Figure 2 and Table 1). The gregarious species, Spratelloides delicatulus, represented $70 \%$ of total fish composition followed by Ambassis natalensis (9\%). Both species were present in large cohorts and uniquely caught at Kirepwe Macho. Sphaeramia orbicularis constituted $50 \%$ of the fish assemblage at Uyombo 1, where eight species were caught, whereas at the adjacent station (Uyombo 2), A. nebulosus individuals represented $44 \%$ of the fish assemblage, with three species encountered in total. On Kirepwe Island (Kirepwe Mark), Sphyraena barracuda represented $20 \%$ of the assemblage found. At this station the highest number of species (18 species) was encountered. Twelve fish species were caught in the second station on the island, Kirepwe Macho, where the most abundant species (S. delicatulus) constituted $81.6 \%$ of the assemblage. In Dabaso, eight species were recorded with Gerres oyena as the dominant species. Two dead mongooses

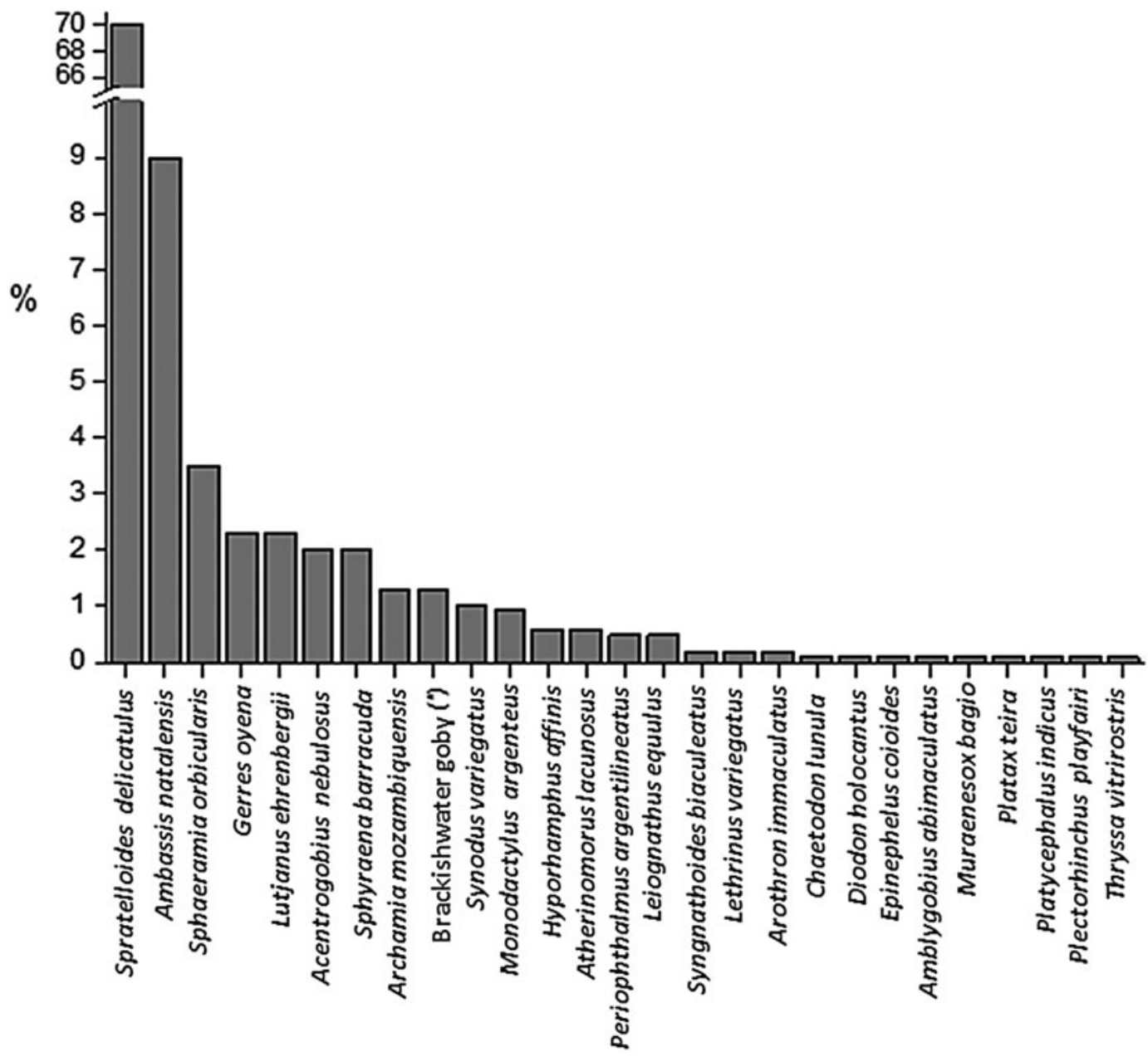

Fig. 2. Histogram of the fish composition of Mida Creek. Fish specimens were caught in July 2011 by means of passive fishing gears (fyke nets, gill nets and beach seine). The sampling period specifically took place during spring tide for $5-6$ consecutive days. $\left({ }^{*}\right)$ indicates that the vernacular name is used because of problems of identification down to a species name. 
Table 1. Overview of the fish composition per sampling site in Mida Creek. Nomenclature is according to Richmond (2002) and to Froese \& Pauly (2011). $\left(^{*}\right)$ indicates that the vernacular name is used because of problems of identification down to a species name. The total number of individuals (N) per species is presented in a separate column.

\begin{tabular}{|c|c|c|c|c|c|c|c|}
\hline \multirow[t]{2}{*}{ Fish family } & \multirow[t]{2}{*}{ Fish species } & \multirow[b]{2}{*}{$\mathbf{N}$} & \multicolumn{5}{|c|}{ Fish composition per station } \\
\hline & & & Uyombo 1 & Uyombo 2 & Kirepwe Mark & Kirepwe Macho & Dabaso \\
\hline Apogonidae & Sphaeramia orbicularis & 33 & $50 \%$ & & $2.0 \%$ & $1.0 \%$ & $11 \%$ \\
\hline Apogonidae & Archamia mozambiquensis & 12 & $22 \%$ & & $3.8 \%$ & & \\
\hline Gobiidae & Acentrogobius nebulosus & 19 & $9.1 \%$ & $44 \%$ & $2.0 \%$ & $0.4 \%$ & $17 \%$ \\
\hline Gobiidae & Brackishwater goby $\left(^{*}\right)$ & 12 & $6.8 \%$ & $39 \%$ & $3.8 \%$ & & \\
\hline Lutjanidae & Lutjanus ehrenbergii & 22 & $5.5 \%$ & & $3.8 \%$ & $2.0 \%$ & $5.6 \%$ \\
\hline Chaetodontidae & Chaetodon lunula & 1 & $2.2 \%$ & & & & \\
\hline Serranidae & Epinephelus coiodes & 1 & $2.2 \%$ & & & & \\
\hline Sphyraenidae & Sphyraena barracuda & 18 & $2.2 \%$ & & $21 \%$ & $0.6 \%$ & $5.7 \%$ \\
\hline Gobiidae & Periophthalmus argentilineatus & 5 & & $17 \%$ & $3.8 \%$ & & \\
\hline Gerreidae & Gerres oyena & 22 & & & $13.4 \%$ & $1.0 \%$ & $33 \%$ \\
\hline Atherinidae & Atherinomorus lacunosus & 6 & & & $11.4 \%$ & & \\
\hline Hemiramphidae & Hyporhamphus affinis & 6 & & & $11.4 \%$ & & \\
\hline Leiognathidae & Leiognathus equulus & 5 & & & $9.6 \%$ & & \\
\hline Gobiidae & Amblygobius albimaculatus & 1 & & & $2.0 \%$ & & \\
\hline Diodontidae & Diodon holocanthus & 1 & & & $2.0 \%$ & & \\
\hline Muraenesocidae & Muraenesox bagio & 1 & & & $2.0 \%$ & & \\
\hline Platycephalidae & Platycephalus indicus & 2 & & & $2.0 \%$ & & \\
\hline Haemulidae & Plectorhinchus playfairi & 1 & & & $2.0 \%$ & & \\
\hline Syngnathidae & Syngnathoides biaculeatus & 2 & & & $2.0 \%$ & $0.1 \%$ & \\
\hline Engraulidae & Thryssa vitrirostris & 1 & & & $2.0 \%$ & & \\
\hline Clupeidae & Spratelloides delicatulus & 657 & & & & $81.6 \%$ & \\
\hline Ambassidae & Ambassis natalensis & 86 & & & & $11 \%$ & \\
\hline Monodactylidae & Monodactylus argenteus & 10 & & & & $1.0 \%$ & $5.7 \%$ \\
\hline Synodontidae & Synodus variegatus & 9 & & & & $1.0 \%$ & $11 \%$ \\
\hline Tetraodontidae & Arothron immaculatus & 2 & & & & $0.2 \%$ & \\
\hline Ephippidae & Platax teira & 1 & & & & $0.1 \%$ & \\
\hline Lethrinidae & Lethrinus variegatus & 2 & & & & & $11 \%$ \\
\hline Number of species & & & 8 & 3 & 18 & 12 & 8 \\
\hline
\end{tabular}

(Mungos mungo) were found in the nets, and they had probably eaten some of the fish.

\section{Length distribution results}

Standard length was measured for 10 species, for which at least six individuals were caught over all stations (Table 2). The proportion of juveniles and adults was identified based on the first maturity length found in Conand (1993), Mees et al. (1999) and Froese \& Pauly (2011), except for Archamia mozambiquensis, A. nebulosus and the brackishwater goby, for which no data about maturity length were available. Data showed that six species (i.e. S. barracuda, Monodactylus argenteus, Synodus variegatus, G. oyena, L. ehrenbergii and $S$. delicatulus) were (almost) exclusively represented by juveniles. Two other species with the juvenile stage dominant, Hyporhamphus affinis and S. orbicularis, had a greater proportion of adults $(33 \%$ and $42 \%$, respectively). The last two species, A. lacunosus and A. natalensis, showed a high abundance of adults, with percentages varying from $76 \%$ to $100 \%$.

\section{Stable isotopes ratios of potential food sources and some invertebrates}

Carbon and nitrogen isotope signatures have been calculated for 13 potential food sources (Table 3). Values of $\delta^{13} \mathrm{C}$ and $\delta^{15} \mathrm{~N}$ showed a high variability. Fresh and senescent mangrove leaves showed the most depleted $\delta^{13} \mathrm{C}$ values $(-31.9 \%$ to $-30.8 \%$ ), while both degradation states of seagrass leaves $(-14.3 \%$ to $-10.6 \%$ o $)$ were more enriched. Phytoplankton $\left(-26.4 \%\right.$ ) had the third most depleted $\delta^{13} \mathrm{C}$ values, but its $\delta^{15} \mathrm{~N}$ result was in the same range as other organisms. The $\delta^{13} \mathrm{C}$ signatures of all different bacteria films varied from $-19.1 \%$ for bacterial mats (Kirepwe Mark) to $-5.3 \%$ for cyanobacteria, whereas $\delta^{15} \mathrm{~N}$ remained similar.

Table 2. Percentage of juveniles and adults and the total number of individuals measured $(\mathrm{N})$ for ten fish species having at least six individuals with minimal and maximal standard length. All individuals were caught in Mida Creek in July 2011.

\begin{tabular}{llrrc}
\hline Fish species & $\begin{array}{l}\text { \% of } \\
\text { juveniles }\end{array}$ & $\begin{array}{l}\text { \% of } \\
\text { adults }\end{array}$ & N & $\begin{array}{l}\text { Minimal and } \\
\text { maximal SL (cm) }\end{array}$ \\
\hline Juvenile stage dominant & & & & \\
$\quad$ Sphyraena barracuda & 100 & 0 & 17 & $5.0 ; 18.1$ \\
Monodactylus argenteus & 100 & 0 & 10 & $3.0 ; 6.0$ \\
Synodus variegatus & 100 & 0 & 9 & $5.0 ; 11.4$ \\
Gerres oyena & 100 & 0 & 22 & $4.0 ; 6.5$ \\
Lutjanus ehrenbergii & 100 & 0 & 22 & $3.6 ; 10.2$ \\
Spratelloides delicatulus & 99 & 1 & 149 & $2.4 ; 4.5$ \\
Hyporhamphus affinis & 67 & 33 & 6 & $8.9 ; 13.5$ \\
Sphaeramia orbicularis & 48 & 42 & 33 & $2.4 ; 8.6$ \\
Adult stage dominant & & & & \\
Atherinomorus lacunosus & 0 & 100 & 6 & $8.7 ; 10.4$ \\
Ambassis natalensis & 24 & 76 & 39 & $2.5 ; 4.8$ \\
\hline
\end{tabular}


Table 3. Stable carbon and nitrogen isotopic signatures of 11 potential food sources and some invertebrates in Mida Creek mangroves (July 2011).

\begin{tabular}{lcc}
\hline Potential food sources & $\boldsymbol{\delta}^{\mathbf{1 3}} \mathbf{C}(\mathbf{\% o})$ & $\boldsymbol{\delta}^{\mathbf{1 5}} \mathbf{N}(\mathbf{\% o})$ \\
\hline Fresh mangrove leaves & -31.9 & 2.7 \\
Senescent mangrove leaves & -30.8 & 4.6 \\
Fresh seagrass leaves & -14.3 & 7.0 \\
Senescent seagrass leaves & -10.6 & 4.0 \\
Phytoplankton & -26.4 & 1.9 \\
Bacterial mat at Kirepwe Mark site & -19.1 & 1.9 \\
Bacterial mat at Kirepwe Macho site & -16.4 & 1.8 \\
Algae at Kirepwe Mark sites & -21.1 & 1.5 \\
Cyanobacteria & -5.3 & 2.9 \\
Red algae & -24.2 & 4.2 \\
Microphytobenthos & -16.2 & 3.3 \\
Sponges & -21.3 & 8.1 \\
Jellyfish & -20.1 & 1.8 \\
\hline
\end{tabular}

The algae group exhibited diverse $\delta^{13} \mathrm{C}$ signatures $(-24.2 \%$ for red algae and $-16.2 \%$ for microphytobenthos) as well as for $\delta^{15} \mathrm{~N}(1.5-4.2 \%)$. Some invertebrate organisms (i.e. sponges and jellyfish) differed from each other in $\delta^{15} \mathrm{~N}$ signatures. Sponge nitrogen signature $(8.1 \%$ ) was higher than jellyfish (1.8\%o).

\section{Stable isotopes ratios of fish species}

Carbon and nitrogen isotope signatures for 14 fish species (three replicates per species, except for $P$. indicus where only two individuals were caught, and for A. nebulosus and L. equulus, for which no samples were used as they were too degraded) from Mida Creek are summarized in Table 4 and Figure 3.
Table 4. Average carbon and nitrogen stable isotope signatures ( \pm standard deviation) for 14 fish species with at least two individuals caught in a mangrove environment (Mida Creek) in July 2011. $\left({ }^{*}\right)$ indicates that vernacular name is used because of problems of identification down to a species name.

\begin{tabular}{lcr}
\hline Fish species & $\boldsymbol{\delta}^{\mathbf{1 3}} \mathbf{C}(\mathbf{\% o})$ & $\boldsymbol{\delta}^{\mathbf{1 5}} \mathbf{N}(\mathbf{\%})$ \\
\hline Sphyraena barracuda & $-16.8 \pm 0.46$ & $10.2 \pm 0.11$ \\
Synodus variegatus & $-16.2 \pm 1.49$ & $10.4 \pm 0.10$ \\
Periophthalmus argentilineatus & $-15.9 \pm 0.15$ & $9.4 \pm 0.41$ \\
Archamia mozambiquensis & $-19.4 \pm 0.77$ & $9.6 \pm 0.42$ \\
Lutjanus ehrenbergii & $-18.1 \pm 0.30$ & $9.1 \pm 0.46$ \\
Brackishwater goby $\left(^{*}\right)$ & $-20.3 \pm 0.25$ & $9.2 \pm 0.51$ \\
Monodactylus argenteus & $-20.9 \pm 1.08$ & $9.0 \pm 0.06$ \\
Sphaeramia orbicularis & $-18.2 \pm 0.42$ & $8.3 \pm 0.17$ \\
Spratelloides delicatulus & $-19.0 \pm 0.15$ & $8.2 \pm 0.10$ \\
Atherinomorus lacunosus & $-18.9 \pm 1.13$ & $8.0 \pm 1.27$ \\
Hyporhamphus affinis & $-19.3 \pm 1.97$ & $8.2 \pm 0.40$ \\
Gerres oyena & $-17.6 \pm 1.54$ & $7.9 \pm 0.52$ \\
Ambassis natalensis & $-20.5 \pm 1.75$ & $7.8 \pm 0.15$ \\
Platycephalus indicus & $-17.6 \pm 0.57$ & $7.8 \pm 0.42$ \\
\hline
\end{tabular}

There was a wide range in consumer $\delta^{13} \mathrm{C}$ values, varying from $-20.9 \pm 1.08 \%$ for $M$. argenteus to $-15.9 \pm 0.15 \%$ for $P$. argentilineatus. In addition, average $\delta^{13} \mathrm{C}$ ratios significantly differed between three species on one hand and the remaining species on the other (ANOVA; $P<0.001$; Df: 13 ; 27; $F=6.34$ ). This resulted in two major groups: (1) highly enriched $\delta^{13} \mathrm{C}$ values for $S$. barracuda, S. variegatus and $P$. argentilineatus; and (2) intermediate $\delta^{13} \mathrm{C}$ values ranging from $-20.9 \%$ o $( \pm 1.08)$ to $-17.6 \%$ o $( \pm 1.54)$ for the remaining 11 species.

These findings were assessed using the $\delta^{15} \mathrm{~N}$ results. Stable nitrogen ratios, indicative of trophic levels, ranged from $7.8 \%$ o $( \pm 0.15)$ for $A$. natalensis to $10.4 \%$ ( \pm 0.1$)$ for

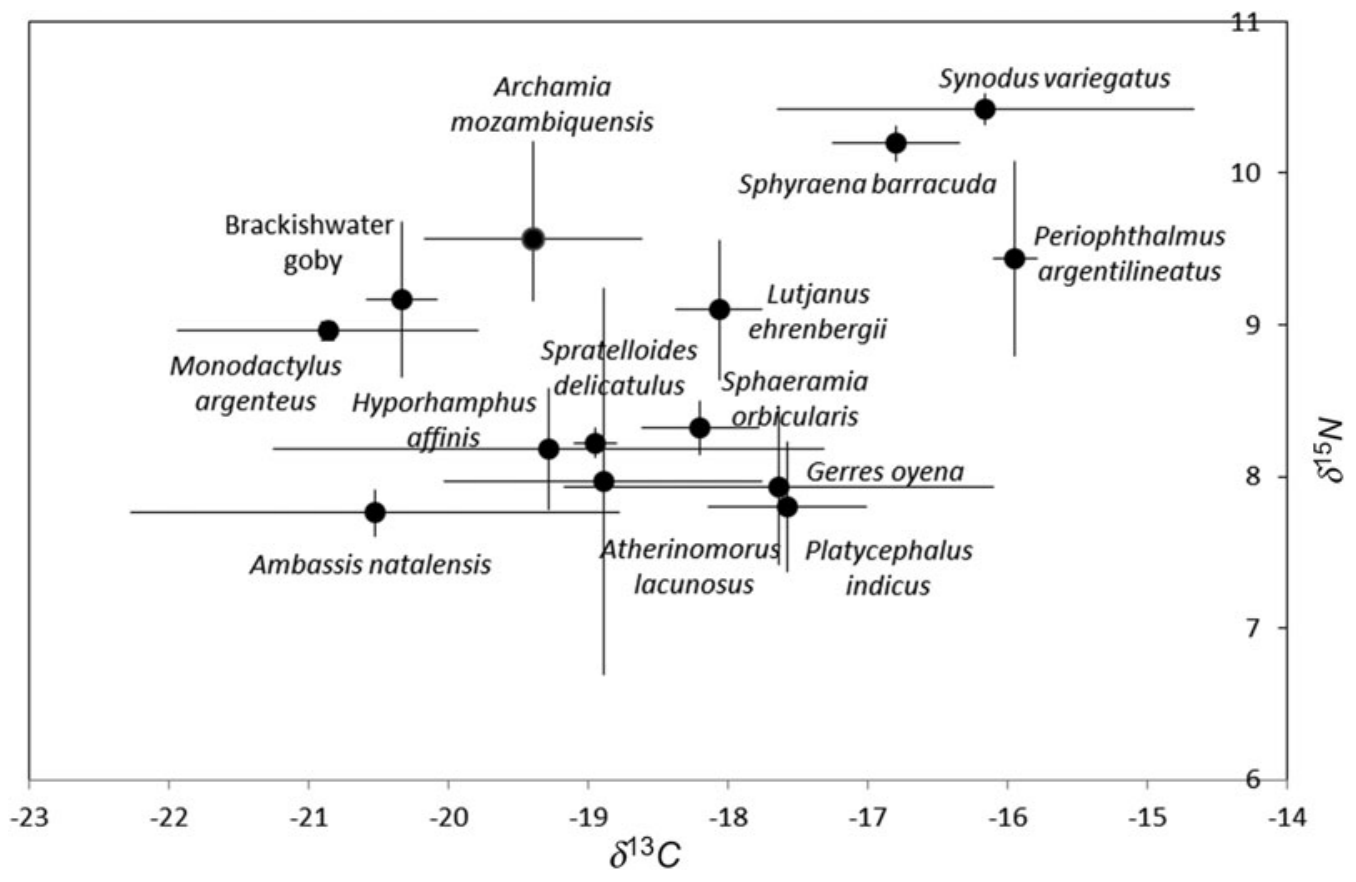

Fig. 3. Plot of $\delta^{13} \mathrm{C}$ and $\delta^{15} \mathrm{~N}$ (average \pm standard deviation) showing spatial variation of 14 fish species caught in Mida Creek (July 2011). Three replicates per species were used (except for Platycephalus indicus, for which only two individuals were caught). 


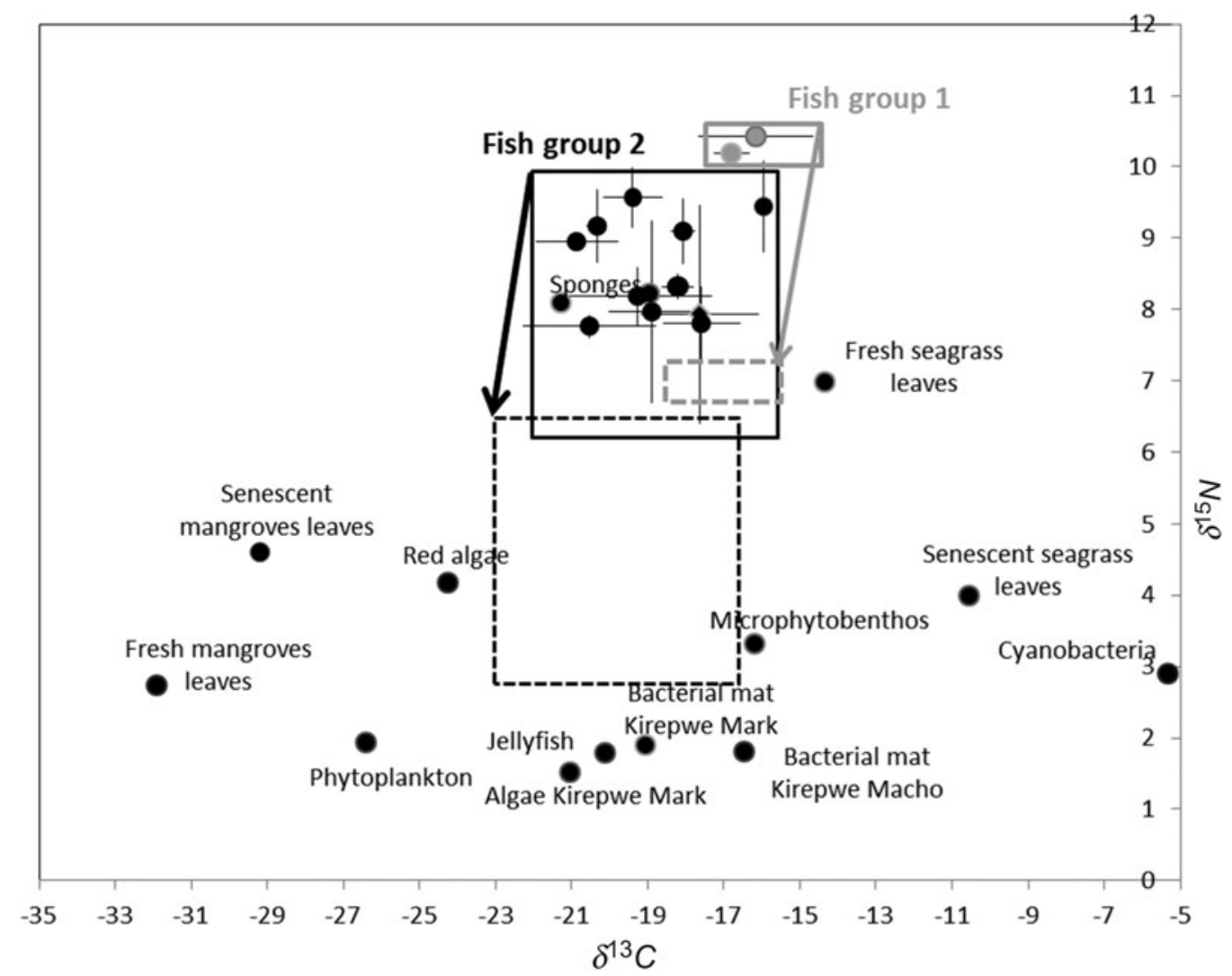

Fig. 4. Plot of $\delta^{13} \mathrm{C}$ and $\delta^{15} \mathrm{~N}$ of potential food sources, some invertebrates and fish species caught in Mida Creek (July 2011), based on significant differences in $\delta^{15} \mathrm{~N}$ values. The solid lines encircle all fish specimens of each group and the dashed lines represent the potential feeding ranges of both fish groups. The arrows represent the differential fractionation of $-3.4 \%$ and $-1.0 \%$ o for, respectively, $\delta^{15} \mathrm{~N}$ and $\delta^{13} \mathrm{C}$.

S. variegatus. There were significant differences in $\delta^{15} \mathrm{~N}$ values between the species (ANOVA; $P<0.001$; d.f.: 13; $27 ; F=$ 9.25) and two separate groups could be identified: (1) species with higher and similar nitrogen values, $S$. barracuda and $S$. variegatus $(10.2 \pm 0.11 \%$ and $10.4 \pm 0.1 \%$, respectively); and (2) all other species showing lower $\delta^{15} \mathrm{~N}$ values (from $7.8 \pm 0.42 \%$ o to $9.6 \pm 0.42 \%$ ).

Considering a differential fractionation of $-3.4 \%$ for $\delta^{15} \mathrm{~N}$ and $-1.0 \%$ for $\delta^{13} \mathrm{C}$, graphically represented by an arrow for each group in Figure 4, the presumed food range values can be identified for the two groups of fishes that significantly differed in $\delta^{15} \mathrm{~N}$ signatures (see dotted light grey and dark boxes, respectively). This figure shows that the ichthyofauna of Mida Creek is not directly feeding on primary producers. Moreover the sponges' dual signature is situated in the carbon and nitrogen values of fish group 2, meaning that these organisms are not included in the diet of fish.

\section{Stomach contents}

The results of stomach contents of eight fish species show that fish were feeding on 20 different food items (Table 5). Detritus were present in stomachs of seven species (except $S$. variegatus) and contributed between $50 \%$ (e.g. H. affinis or M. argenteus) and $100 \%$ (e.g. L. equulus) of the diet (SIMPER results). Crustaceans also were part of the diet of seven species.

Significant differences in stomach content composition between species were found (ANOSIM global test statistic $R=0.315 ; P<0.001)$. The stomach contents of juveniles belonging to $S$. barracuda species differed from $S$. orbicularis and $G$. oyena; while $S$. variegatus significantly differed from the brackish water goby, G. oyena and S. orbicularis. Sphyraena barracuda and $S$. variegatus individuals differed largely from the others by the consumption of bony fish, which prey was, respectively, present in the stomachs of $50 \%$ of individuals and $100 \%$ of individuals (SIMPER results). These results confirm the solely piscivorous diet of $S$. variegatus and the partial piscivorous feeding regime of $S$. barracuda when individuals are immature. Significant differences were also found between S. orbicularis and the brackish water goby and G. oyena. This difference is due to the absence of macroalgae in all stomachs of $S$. orbicularis individuals, whereas the average occurrence of this food item in the stomachs of the brackishwater goby and G. oyena reached, respectively, 50\% and 65\% (SIMPER results). Moreover, the stomachs of all individuals of S. orbicularis showed preferences for crustaceans, especially Gammaridae (the average abundance of all dissected stomachs reached 55\%, SIMPER results); whereas they were not present in any stomachs of the brackish water goby and only in $18 \%$ of G. oyena individuals (SIMPER results).

\section{DISCUSSIDN}

\section{The species composition of the fish assemblage of Mida Creek}

Although Mida Creek has been a protected area since 1979, there are no published data on its ichthyofauna. Indeed 
Table 5. Presence/absence matrix of stomach contents of individuals belonging to eight different fish species caught in a mangrove environment (Mida Creek) in July 2011 indicating on which food items they were feeding. $\left({ }^{*}\right)$ indicates that vernacular name is used because of problems of identification down to a species name. $\mathrm{N}$, the number of individuals.

\begin{tabular}{|c|c|c|c|c|c|c|c|c|c|c|c|c|c|c|c|c|c|c|c|c|c|c|c|}
\hline \multirow[b]{4}{*}{ Fish species } & \multirow[b]{4}{*}{$\mathbf{N}$} & \multirow[b]{4}{*}{ 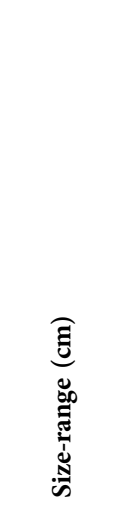 } & \multirow[b]{4}{*}{ 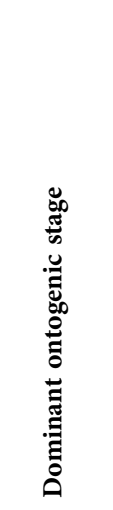 } & \multicolumn{20}{|c|}{ Food items } \\
\hline & & & & \multirow[b]{3}{*}{$\begin{array}{l}\text { कే } \\
\text { 音 }\end{array}$} & \multirow[b]{3}{*}{ 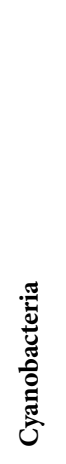 } & \multirow[b]{3}{*}{ 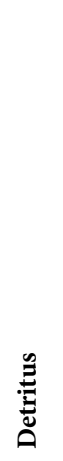 } & \multirow[b]{3}{*}{ 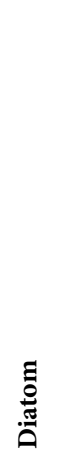 } & \multirow[b]{3}{*}{ 点 } & \multirow[b]{3}{*}{ 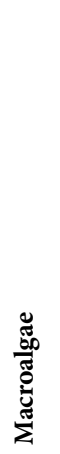 } & \multirow[b]{3}{*}{$\overline{\bar{\Xi}}$} & \multicolumn{13}{|c|}{ Crustaceans } \\
\hline & & & & & & & & & & & \multicolumn{10}{|c|}{ Malascostraca } & \multicolumn{3}{|c|}{ Maxillo-poda } \\
\hline & & & & & & & & & & & $\begin{array}{l}\text { 蒿 } \\
\text { 言 } \\
\text { 产 }\end{array}$ & 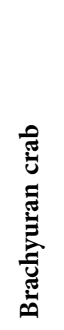 & जै & 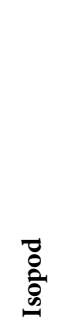 & 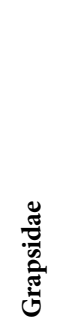 & 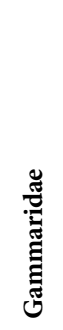 & 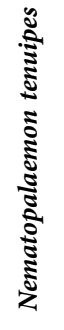 & 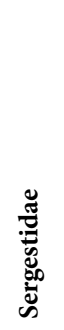 & 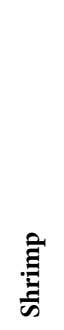 & હ્ّ & 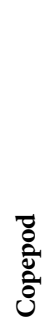 & 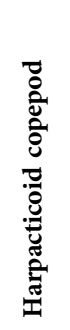 & 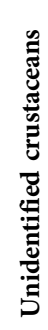 \\
\hline Sphyraena barracuda & 14 & $5.0-13.9$ & Juvenile & 1 & o & 1 & 0 & 0 & 1 & 0 & 1 & o & 0 & 0 & 0 & 0 & 1 & 0 & 1 & 0 & 0 & 0 & 1 \\
\hline Synodus variegatus & 4 & $5.0-11.4$ & Juvenile & 1 & o & 0 & 0 & 0 & 0 & 0 & o & 0 & 0 & 0 & 0 & 0 & 0 & 0 & 0 & 0 & 0 & 0 & 0 \\
\hline Brackishwater goby $\left(^{*}\right)$ & 10 & $7.7-21.5$ & 1 & 0 & 0 & 1 & 0 & 1 & 1 & 1 & 0 & 0 & 1 & 1 & 1 & 0 & 0 & 0 & 1 & 0 & 0 & 0 & 1 \\
\hline Gerres oyena & 17 & $4.3-6.0$ & Juvenile & 0 & 1 & 1 & 1 & 0 & 1 & 1 & 1 & 0 & 0 & 0 & 0 & 1 & 0 & 0 & 1 & 0 & 1 & 1 & 1 \\
\hline Hyporhamphus affinis & 4 & $8.9-13.5$ & Juvenile & 0 & o & 1 & 0 & 0 & o & 0 & o & 0 & 0 & 0 & 0 & 0 & 0 & 0 & 0 & 0 & 0 & 0 & 1 \\
\hline Leiognathus equulus & 4 & $6.4-7.8$ & Juvenile & 0 & 0 & 1 & 0 & 0 & 1 & 0 & o & 0 & 0 & 0 & 0 & 0 & 0 & 0 & 0 & 0 & 0 & 0 & 1 \\
\hline Monodactylus argenteus & 5 & $3.5-6.0$ & Juvenile & 0 & o & 1 & 1 & 0 & 0 & 0 & 1 & 0 & 0 & 1 & 0 & 0 & 0 & 0 & 0 & 0 & 1 & 1 & 1 \\
\hline Sphaeramia orbicularis & 22 & $2.4-8.6$ & Juvenile & 0 & 0 & 1 & 0 & 0 & 0 & 1 & 1 & 1 & 0 & 1 & 0 & 1 & 0 & 1 & 1 & 1 & 0 & 1 & 1 \\
\hline
\end{tabular}


most of the ecological studies on fish assemblages from Kenyan mangroves focus on Gazi Bay and other forests situated on the south coast, in the vicinity of Mombasa. At a regional scale, the fish composition of mangroves along the Kenyan coast seems quite variable. In Gazi Bay, over a year, 129 teleost species were identified, of which Gerreidae and Atherinidae were the dominant families, with their individuals composing $77 \%$ of the total catch (Kimani et al., 1996). However, based on two recent inventory studies, respectively 42 and 50 fish species were found in Gazi Bay (Crona \& Rönnbäck, 2007; Nyunja et al., 2009). In another Kenyan mangrove forest, Ungwana Bay on the Rasi Ngomeni peninsula, the maximum number of species recorded was 35 species for a sampling effort covering a year, with Clupeidae, Engraulidae, Leiognathidae, Sillaginidae and Gerreidae being the most abundant families in terms of number of species (Mirera et al., 2010). In Mida Creek, 27 fish species were recorded, with the highest numbers of a Clupeidae species, $S$. delicatulus. Clupeids are fish of relatively small size (i.e. a total length of maximum $7 \mathrm{~cm}$ ) which form large cohorts (Froese \& Pauly, 2011) and can be caught in large numbers with one haul of a net. Several authors have previously singled out the Clupeidae as the main contributor to the mangrove fish assemblage (Mirera et al., 2010) including Gazi Bay (Huxham et al., 2004).

Mida, Gazi and Ungwana mangroves exhibit different physico-chemical features that possibly explain the differences between their fish communities, although difference in sampling strategy and intensity may cause differences as well. Mida has only a freshwater input through groundwater and precipitation, whereas the main Gazi channel drains the Kidogoweni River (Nyunja et al., 2009). The major physical feature differing between Ungwana and Mida is the freshwater discharge from the Tana and Sabaki rivers, and the influence of the colder waters from the Somali Current in Ungwana Bay (Obura, 2001). For instance, one fishing ground, Formasa, in front of Ungwana, shows an abundance of freshwater fish families (i.e. Cichlidae and Clariidae), whereas, in another known fishing place closer to Mida, the more abundant families recorded occur in saltwater (Munga et al., 2012). The season of sampling may also contribute to a shift in fish species composition. As illustrated by Wakwabi \& Mees (1999) for Tudor Creek, the period from May to August is the typical long rainy season during which the fish species number is the smallest. In fact, fish mortality seemed to increase during that period of the year but did not affect the major taxa (Mwandya et al., 2010). Our field sampling was done in July, during the south-east monsoon which brings considerable rainfall and likely also explains the low number (27) of species recorded.

The composition of fish catches can also strongly depend on the technique used. All studies performed in Mida Creek, Gazi Bay and Ungwana Bay used diverse passive fishing gears (e.g. beach seine or stake-nets) with different sizes of mesh and also with various sizes of opening.

A general trend in the decrease of abundance of species richness along the Kenyan coastline is also observed. In the 1990 s the sizes of the total catch were bigger (e.g. up to 19,000 fish) and the species number greater (e.g. from 75 to 128 teleost species) (De Troch et al., 1996; Kimani et al., 1996), while in the most recent surveys, only 40-50 species as a maximum have been recorded, and total catches are lower (Crona \& Rönnbäck, 2007; Nyunja et al., 2009;
Munga et al., 2010). This observed decline needs further confirmation by standardized comparisons between past and future inventories. To conclude, the results of the fish species composition of Mida Creek represent the typical situation for a tropical ecosystem, with one or two dominant species and many less abundant ones (Kimani et al., 1996; Mirera et al., 2010). Nevertheless, the relatively low number of species recorded compared with older studies from adjacent areas is probably also influenced by the period of sampling (i.e. season) and/or by the sampling technique, but this has to be further investigated. A continuous survey conducted throughout the year might give the exact picture of available teleost fish species.

\section{The population structure of the ichthyofauna}

Most of the individuals caught during our survey were juveniles, while adult specimens were represented by individuals of small size (maximum $10 \mathrm{~cm}$ ). In Mida Creek, the immature fish were more abundant than adults, as the population of the numerically more abundant species (i.e. S. delicatulus) was represented by $99 \%$ juveniles, and contributed to $70 \%$ of the total fish composition (Table 2; Figure 2). Our results indicate that mangroves may serve as a nursery ground. Most individuals of S. barracuda, M. argenteus, S. variegatus, G. oyena, $L$. ehrenbergii, $S$. delicatulus and $H$. affinis were found at juvenile stage in the studied mangroves. All these species would probably occupy the mangrove waters for a very limited period, to feed or to escape from predators. These species could be so-called transient species because they may spend an important part of their time in mangrove creeks during low tide when no other suitable protective habitats are available in the neighbourhood, and/or migrate to other ecosystems (e.g. coral reefs) due to a shift in ontogeny (Mwandya et al., 2010; Kimirei et al., 2011, 2013). For instance, they may migrate to mudflat areas as they become less vulnerable to predation and are able to forage safely in more open and less protected habitats (Laegdsgaard \& Johnson, 2001). Nagelkerken et al. (2002) have already suggested that $S$. barracuda is a species with possible dependence on mangrove and/or seagrass as nursery habitat, and our study supports their statement. The juveniles of this circumtropical species were only encountered in the mangrove environment, while adults were present on coral reefs. Given our restricted sampling strategy (i.e. net removal after $24 \mathrm{~h}$ ), our assumptions about fish migration toward other ecosystems need to be taken with caution. Besides, a trade-off seems to exist between food abundance/growth rate and predation pressure/mortality risk, where fish specifically chose habitats which minimize the ratio of mortality risk to growth rate (Grol et al., 2008).

The population of S. orbicularis in Mida Creek consisted of almost 50\% adults. Results from research performed by Mees et al. (1999) suggested that this species is a permanent resident in swamp forests, forming small aggregations resting in the rhizophores. The cohort of both juveniles and adults at Uyombo 1 constituted the dominant species. This station is the most remote place in the mangrove forest, where permanent pools are formed, suggesting that they probably live into the root complex of mangrove forests throughout their ontogeny.

Two species, A. natalensis and A. lacunosus, were represented, respectively, by 76 and $100 \%$ of adult individuals in 
Mida Creek. Atherinomorus lacunosus form large schools along sandy shorelines and reef margins (Froese \& Pauly, 2011). The few adult individuals caught in Mida Creek (six specimens; Table 2) may indicate that, when maturity is reached, young adults move to other less protected environments, such as coral reefs. Juveniles of A. natalensis as well as young adults were found in mangroves, but along the south coast of Africa (Mvoti estuary), it has been reported that this ambassid fish is an eurytopic species which is able to live in freshwater (Whitfield, 1998; Froese \& Pauly, 2011; Swemmer, 2011). This species is, thus, well adapted to live in the dynamic mangrove ecosystem where environmental conditions (e.g. salinity) vary substantially.

\section{The trophic interactions of fish in mangroves}

Mangrove forests are often considered as ecosystems offering important provision of food sources for the ichthyofauna (Lugendo et al., 2007), but this role still remains controversial. In the present study, we used dual isotopic signatures of ${ }^{13} \mathrm{C}$ and ${ }^{15} \mathrm{~N}$, which is a technique applied as an indicator of the trophic level. Stable isotope analysis is based on two assumptions: (1) different primary producers may exhibit diverse $\delta^{13} \mathrm{C}$ values due to different pathways of photosynthesis ( $\mathrm{C}_{3}$ or CAM for crassulacean acid metabolism species) or the diverse potential inorganic carbon sources; and (2) a consistent degree of fractioning occurs between the isotopic signal of the prey and the consumer (Bouillon et al., 2002; Layman, 2007).

Stable isotope results highly suggest that the fish assemblage of Mida creek can be separated into two functional groups reflecting their trophic mode: (1) the mainly piscivorous species; and (2) a more heterogeneous group of zoobenthivorous/omnivorous species.

Synodus variegatus and S. barracuda are found higher in the food web, given their high $\delta^{15} \mathrm{~N}$ values, and are considered as fish predators due to the presence of bony fish in their stomachs. The piscivorous diet of $S$. barracuda through all life stages has already been identified by De Troch et al. (1996, 1998) in Gazi Bay, but crustaceans, amphipods and shrimps were also found in the guts of juveniles collected in this present study and also in individuals from research conducted by Lugendo et al. (2006). Synodus variegatus feeds on small fish from passing schools (Froese \& Pauly, 2011). These fish were mainly present in Kirepwe Macho, where large groups of clupeids (i.e. S. delicatulus) were encountered.

The group of zoobenthivorous/omnivorous species is a heterogeneous one, which encompasses fish which do not significantly differ in their diet, except for S. orbicularis, the brackish water goby and G. oyena. Our results indicate that the orbiculate cardinalfish (S. orbicularis) mainly feed on crustaceans confirming previous findings in Mees et al. (1999). All the other species show overlaps in diet, partially feed on crustaceans (e.g. shrimps, crabs and copepods) or on macroalgae. A study carried out in Mtwapa Creek indicated that the trophic niches of S. delicatulus and A. lacunosus highly overlapped because they utilized the same food source, copepods (Mavuti et al., 2004).

The values of $\delta^{13} \mathrm{C}$ in collected fish do not show any direct feeding link with primary producers, including the mangrove leaves at different stages of degradation. Mangrove associated primary producers (e.g. phytoplankton, seagrass and algae) do not appear to be direct food sources for the fish species studied. Fish group 1, only composed of two predatory species, seems to feed on fish group 2, comprising 12 species. Through data in the literature we found that the presumed feeding range values of the fish group $2(-16 \%$ to $-23 \%$ or $\delta^{13} \mathrm{C}$ and $3-6.5 \%$ for $\delta^{15} \mathrm{~N}$ ) fitted into the data for molluscs and crabs of Bouillon et al. (2004) from similar and adjacent mangrove ecosystems. The observed feeding range of fish group 2 in Mida Creek includes the typical mangrove bottom invertebrates, non-benthic fish larvae and zooplankton. It supports the idea that the fish diet relies on the secondary consumers living within this ecosystem. In a perspective to assess the feeding function of mangroves, albeit in an indirect manner through invertebrates, evidence of direct consumption of leaves by these invertebrates has to be investigated in the future.

Only a limited number of studies using stable isotope signatures have included mangrove-inhabiting invertebrates (Newell et al., 1995; Loneragan et al., 1997; Bouillon et al., 2002; Pape et al., 2008; Kruitwagen et al., 2010). Their results suggest that most crustaceans show a high dependence on microphytobenthos (e.g. Littoraria scabra or Terebralia palustris) growing on mangrove substratum or on epiphytes from seagrass beds (e.g. juvenile prawns), while Sesarma crabs directly feed on mangrove products (i.e. leaves and detritus) (Newell et al., 1995; Loneragan et al., 1997; Pape et al., 2008; Kruitwagen et al., 2010). There is still a scarcity of knowledge about the overall marine community of invertebrates, especially from East Africa. Future research comparing isotopic values of carbon sources found in mangroves with invertebrate signatures from Mida Creek should assess this concept and enlighten the essential trophic role of mangroves.

\section{CONCLUSION}

The present study explored the ichthyofauna of Kenyan mangrove forests at Mida Creek.

Small-sized fish with a wide geographical distribution (belonging to Clupeidae and Ambassidae) are the dominant species in Mida Creek. The ichthyofauna in these mangroves mainly consist of transient species (e.g. coral or seagrass associated). Juveniles were numerically more abundant in the Creek than adults, supporting the hypothesis of a nursery function for mangrove forests. By using stable isotopes and stomach content analyses we showed that the fish assemblage can be divided into two functional groups: (1) mainly piscivorous species (S. barracuda and S. variegatus); and (2) zoobenthivorous/omnivorous species (mostly belonging to Ambassidae, Clupeidae and Apogonidae families) feeding on small benthic and pelagic invertebrates.

\section{ACKNDWLEDGEMENTS}

The authors would like to thank Professor Dr Steven Bouillon and Zita Kelemen (University of Leuven) for giving us access to IRMS facilities, Francesca Pasotti (University of Ghent) for her help during the preparation process of stable isotope samples, Dixon Odongo (Kenyan Marine and Fisheries Research Institute) for his help in fieldwork and fish identification and also to Dr Bruno Frédérich (University of Liège) for his help during the process of drafting this paper. 


\section{FINANCIAL SUPPDRT}

This study was financially supported by the Kenya-Belgium IUC-RIP Project implemented at the University of Nairobi (Kenya) and by the VLIR-UOS travel grant (L.G., 2011) for students in the Flemish Community.

\section{REFERENCES}

Abuodha P.A. and Kairo J.G. (2001) Human-induced stresses on mangrove swamps along the Kenyan coast. Hydrobiologia 458, 255-256.

Beck M.W., Heck K.L., Able K.W., Childers D.L., Eggleston D.B., Gillanders B.M., Halpern B., Hays C.G., Hoshino K., Minello T.J., Orth R.J., Sheridan P.F. and Weinstein M.R. (2001) The identification, conservation, and management of estuarine and marine nurseries for fish and invertebrates. BioScience 51, 633-641.

Bouillon S., Koedam N., Raman A.V. and Dehairs F. (2002) Primary producers sustaining macro-invertebrates communities in intertidal mangrove forests. Oecologia 130, 441-448.

Bouillon S., Moens T., Overmeer I., Koedam N. and Dehairs F. (2004) Resource utilization patterns of epifauna from mangrove forests with contrasting inputs of local versus imported organic matter. Marine Ecology Progress Series 278, 77-88.

Clarke K.R and Green R.H. (1988) Statistical design and analysis for a 'biological effects' study. Marine Ecology Progress Series 46, $213-226$.

Clarke K.R. (1993) Non-parametric multivariate analysis of changes in community structure. Australian Journal of Ecology 18, 117-143.

Cocheret de la Morinière E., Pollux B.J.A., Nagelkerken I., Hemminga M.A., Huiskes A.H.L. and van der Velde G. (2003) Ontogenetic dietary changes of coral reef fishes in the mangrove-seagrass-reef continuum: stable isotopes and gut-content analysis. Marine Ecology Progress Series 246, 279-289.

Conand F. (1993) Life history of silverside Atherinomorus lacunosus (Atherinidae) in New Caledonia. Journal of Fish Biology 42, 851-863.

Crona B.I. and Rönnbäck P. (2007) Community structure and temporal variability of juvenile fish assemblages in natural and replanted mangroves, Sonneratia alba, Sm., of Gazi Bay, Kenya. Estuarine, Coastal and Shelf Science 74, 44-52.

Dahdouh-Guebas F., Mathenge C., Kairo J.G. and Koedam N. (2000) Utilization of mangrove wood products around Mida Creek (Kenya) amongst subsistence and commercial users. Economic Botany 54, $513-527$.

Dahlgren C.P., Kellison G.T., Adams A.J., Gillanders B.M., Kendall M.S., Layman C.A., Ley J.A., Nagelkerken I. and Serafy J.E. (2006) Marine nurseries and effective juvenile habitats: concepts and applications. Marine Ecology Progress Series 312, 291-295.

De Troch M., Mees J., Papadopoulos I. and Wakwabi E.O. (1996) Fish communities in a tropical bay (Gazi Bay, Kenya): seagrass beds vs. unvegetated areas. Netherlands Journal of Zoology 46, $236-252$.

De Troch M., Mees J. and Wakwabi E.O. (1998) Diets of abundant species from beach seine catches in seagrass beds of a tropical bay (Gazi Bay, Kenya). Belgian Journal of Zoology 128, 135-144.

Deepayan S. (2008) Lattice: multivariate data visualization with $R$. 2nd edition. New York: Springer.

Ewel K.C., Twilley R.R. and Ong J.E. (1998) Different kinds of mangrove forests provide different goods and services. Global Ecology and Biogeography Letters 7, 83-94.
Froese R. and Pauly D. (2011) FishBase. Available at: www.fishbase.org (accessed 11 February 2014).

Fry B. and Ewel K.C. (2003) Using stable isotopes in mangrove fisheries research-a review and outlook. Isotopes in Environmental and Health Studies 39, 191-196.

Giri C., Ochieng E., Tieszen L.L., Zhu Z., Singh A., Loveland T., Masek J. and Duke N. (2011) Status and distribution of mangrove forests of the world using earth observation satellite data. Global Ecology and Biogeography 20, 154-159.

Government of Kenya (GOK) (1989) Kilifi District Development Plan, 1989-1999. Nairobi: Ministry of Planning and National Development, 224 pp.

Grol M.G.G., Dorenbosch M., Kokkelmans E.M.G. and Nagelkerken I. (2008) Mangroves and seagrass beds do not enhance growth of early juveniles of a coral reef fish. Marine Ecology Progress Series 366, $137-146$.

Huxham M., Kimani E. and Augley J. (2004) Mangrove fish: a comparison of community structure between forested and cleared habitats. Estuarine, Coastal and Shelf Science 60, 637-647.

Hyslop D.J. (1980) Stomach content analysis-a review of methods and their application. Journal of Fish Biology 7, 411-429.

Igulu M.M., Nagelkerken I., van der Velde G. and Mgaya Y.D. (2013) Mangrove fish production is largely fuelled by external food sources: a stable isotope analysis of fishes at the individual, species, and community levels from across the globe. Ecosystems. Doi: 10.1007/ s10021-013-9687-7.

Jackson C. (2010) The birds of Mida Creek, Kenya $\left[3^{\circ} 22^{\prime} S, 39^{\circ} 58^{\prime} E\right]$. National Museums of Kenya, A Rocha Kenya and Department of Ornithology.

Kairo J.G. and Bosire J. (2009) Ecology and restoration of mangrove forests in Kenya. Nature and Fauna 24, 42-49.

Kairo J., Dahdouh-Guebas F., Gwada P., Ochieng C. and Koedam N. (2002) Regeneration status of mangrove forests in Mida Creek, Kenya: compromised or secured future? Ambio 31, 7-8.

Kathiresan K. and Rajendran N. (2005) Mangrove ecosystems of the Indian Ocean region. Indian Journal of Marine Sciences 34, 104-113.

Kennedy A. (1988) Mida Creek-a study of human impact. PhD thesis. University of Edinburgh, UK.

Kimani E.N., Mwatha G.K., Wakwabi E.O., Ntiba J.M. and Okoth B.K. (1996) Fishes of a shallow tropical mangrove estuary, Gazi, Kenya. Marine Freshwater Restoration 47, 857-868.

Kimirei I.A., Nagelkerken I., Griffioen B., Wagner C. and Mgaya Y.D. (2011) Ontogenetic habitat use by mangrove/seagrass associated coral reef fishes shows flexibility in time and space. Estuarine, Coastal and Shelf Science 92, 47-58.

Kimirei I., Nagelkerken I., Mgaya Y.D. and Huijbers C.M. (2013) The mangrove nursery paradigm revisited: otolith stable isotopes support nursery-to-reef movements by Indo-Pacific fishes. PLoS ONE 8, e66320. doi:10.1371/journal.pone.0066320.

Kruitwagen G., Nagelkerken I., Lugendo B.R., Mgaya Y.D. and Wendelaar Bonga S.E. (2010) Importance of different carbon sources for macroinvertebrates and fishes of an interlinked mangrovemudflat ecosystem (Tanzania). Estuarine, Coastal and Shelf Science 88, 464-472.

Laegdsgaard P. (1996) The ecological significance of subtropical mangrove habitats to juvenile fish. $\mathrm{PhD}$ thesis. University of Queensland, Australia.

Laegdsgaard P. and Johnson C. (2001) Why do juvenile fish utilise mangrove habitats? Journal of Experimental Biology and Ecology 257, $229-253$. 
Layman C.A. (2007) What can stable isotope ratios reveal about mangroves as fish habitat? Bulletin of Marine Science 80, 513-527.

Loneragan N.R., Bunn S.E. and Kellaway D.M. (1997) Are mangroves and seagrasses sources of organic carbon for penaeid prawns in a tropical Australian estuary? A multiple stable-isotope study. Marine Biology 130, 289-300.

Lorrain A., Savoye N., Chauvaud L., Paulet Y.M. and Naulet N. (2003) Decarbonation and preservation method for the analysis of organic $\mathrm{C}$ and $\mathrm{N}$ contents and stable isotope ratios of lowcarbonated suspended particulate material. Analytica Chimica Acta 491, 125-133.

Lugendo B.R., Nagelkerken I., Kruitwagen G., van der velde G. and Mgaya Y.D. (2007) Relative importance of mangroves as feeding habitats for fishes: a comparison between mangrove habitats with different settings. Bulletin of Marine Science 80, 497-512.

Lugendo B.R., Nagelkerken I., van der Velde G. and Mgaya Y.D. (2006) The importance of mangroves, mud and sand flats, and seagrass beds as feeding areas for juvenile fishes in Chwaka Bay, Zanzibar: stomach content and stable isotope analyses. Journal of Fish Biology 69, $1639-1661$.

Lugendo B.R., Pronker A., Cornelissen I., de Groene A., Nagelkerken I., Dorenbosch M., van der Velde G. and Mgaya Y.D. (2005) Habitat utilisation by juveniles of commercially important fish species in a marine embayment in Zanzibar, Tanzania. Aquatic Living Resources 18, 149-158.

Mavuti K.M., Nuynja J.A. and Wakwabi E.O. (2004) Trophic ecology of some common juvenile fish species in Mtwapa Creek, Kenya. Western Indian Ocean Journal Marine Science 3, 179-187.

Mees J., Mwamsojo G.U. and Wakwabi E.O. (1999) Aspects of the biology and feeding ecology of the orbiculate cardinalfish Sphaeramia orbicularis (Cuvier; 1828) (Teleostei: Apogonidae) in a Kenyan mangrove forest. Biology Jaarb Dodonaea 66, 134-145.

Mirera D.O., Kairo J.G., Kimani E.N. and Waweru F.K. (2010) A comparison between fish assemblages in mangrove forests and on intertidal flats at Ungwana Bay, Kenya. African Journal of Aquatic Science 35, 165-171.

Moberg F. and Rönnbäck P. (2003) Ecosystems services of the tropical seascape: interactions, substitutions and restoration. Ocean and Coastal Management 46, 27-46.

Munga C.N., Mohamed M.O.S., Obura D.O., Vanreusel A. and Dahdouh-Guebas F. (2010) Resource users' perceptions on continued existence of the Mombasa Marine Park and Reserve, Kenya. Western Indian Ocean Journal of Marine Science 9, 213-225.

Munga C., Ndegwa S., Fulanda B., Manyala J., Kimani E., Ohtomi J. and Vanreusel A. (2012) Bottom shrimp trawling impacts on species distribution and fishery dynamics: Ungwana Bay fishery Kenya before and after the 2006 trawl ban. Fisheries Science 78, 209-219.

Mwaluma J., Osore M.K.W., Kamau J. and Wawiye P. (2003) Composition, abundance and seasonality of zooplankton in Mida Creek, Kenya. Western Indian Ocean Journal Marine Science 2, $147-155$.

Mwandya A.W., Gullstrom M., Andersson M.H., Ohman M.C., Mgaya Y.D. and Bryceson I. (2010) Spatial and seasonal variations of fish assemblages in mangrove Creek systems in Zanzibar (Tanzania). Estuarine, Coastal and Shelf Science 89, 277-286.

Nagelkerken I. (2009) Evaluation of nursery function of mangroves and seagrass beds for tropical decapods and reef fishes: patterns and underlying mechanisms. In Nagelkerken I. (ed.) Ecological connectivity among tropical coastal ecosystems. Dordrecht: Springer Science and Business Media, pp. 357-399.
Nagelkerken I., Blaber S.J.M., Bouillon S., Green P., Haywood M., Kirton L.G., Meynecke J.O., Pawlik J., Penrose H.M., Sasekumar A. and Somerfield P.J. (2008) The habitat function of mangroves for terrestrial and marine fauna: a review. Aquatic Botany 89, $155-185$.

Nagelkerken I., De Schryver A.M., Verweij M.C., Dahdouh-Guebas F., van der Velde G. and Koedam N. (2010) Differences in root architecture influence attraction of fishes to mangroves: a field experiment mimicking roots of different length, orientation and complexity. Journal of Experimental Marine Biology and Ecology $396,27-34$.

Nagelkerken I., Grol M.G.G. and Mumby P.J. (2012) Effects of marine reserves versus nursery habitat availability on structure of reef fish communities. PLoS ONE 7, e36906. doi: 10.1371/journal.pone. 0036906.

Nagelkerken I., Roberts C.M., van der Velde G., Dorenbosch M., van Riel M.C., Cocheret de la Morinière E. and Nienhuis P. (2002) How important are mangroves and seagrass beds for coral-reef fish? The nursery hypothesis tested on island scale. Marine Ecology Progress Series 244, 299-305.

Nakamura Y., Horinouchi M., Shibuno T. and Tanak Y. (2008) Evidence of ontogenetic migration from mangroves to coral reefs by black-tail snapper Lutjanus fulvus: stable isotope approach. Marine Ecology Progress Series 355, 257-266.

Newell R.I.E., Marshall N., Sasekumar A. and Chong V.C. (1995)Relative importance of benthic microalgae, phytoplankton, and mangroves as sources of nutrition for penaeid prawns and other coastal invertebrates from Malaysia. Marine Biology 123, 595-606.

Nieuwenhuizen J., Maas Y.E.M. and Middelburg J. (1994) Rapid analysis of organic carbon and nitrogen in particulate materials. Marine Chemistry 45, 217-224.

Nyunja J., Ntiba M., Onyari J., Mavuti K., Sotaert K. and Bouillon S. (2009) Carbon sources supporting a diverse fish community in a tropical coastal ecosystem (Gazi Bay, Kenya). Estuarine, Coastal and Shelf Science 83, 333-341.

Obura D.O. (2001) Kenya. Marine Pollution Bulletin 42, 1264-1278.

Osore M.K.W., Mwaluma J.M., Fiers F. and Daro M.H. (2004) Zooplankton composition and abundance in Mida Creek, Kenya. Zoological Studies 43, 415-424.

Pape E., Muthumbi A., Kamanu C.P. and Vanreusel A. (2008) Size-dependent distribution and feeding habits of Terebralia palustris in mangrove habitats of Gazi Bay, Kenya. Estuarine, Coastal and Shelf Science 76, 797-808.

Polidoro B.A., Carpenter K.E., Collins L., Duke N.C., Ellison A.M., Ellison J.C., Farnsworth E.J., Fernando E.S., Kathiresan K., Koedam N., Livingstone S.R., Miyagi T., Moore G.E., Ngoc Nam V., Ong J.E., Primavera J.H., Salmo S.G., Sanciangco J.C., Sukardjo S., Wang Y. and Hong Yong J.W. (2010) The loss of species: mangrove extinction risk and geographic areas of global concern. PLoS ONE 5, e10095. doi: 10.1371/journal.pone.001009.

Primavera J.H. (1997) Fish predation on mangrove-associated penaeids: the role of structures and substrate. Journal of Experimental Marine Biology and Ecology 215, 205-216.

R Development Core Team (2008) R: a language and environment for statistical computing. Vienna: $\mathrm{R}$ Foundation for Statistical Computing; available at: http://www.R-project.org (accessed 11 February 2014).

Richmond M.D. (2002) A field to the seashores of Eastern Africa and the Western Indian Ocean Islands. 2nd edition. Sweden: SIDADepartment for Research Cooperation, SAREC. 
Rönnbäck P., Crona B. and Ingwall L. (2007) The return of ecosystem goods and services in replanted mangrove forests: perspectives from local communities in Kenya. Environmental Conservation 34, $313-324$.

Sarakinos H.C., Johnson M.L. and Zanden M.J.V. (2002) A synthesis of tissue-preservation effects on carbon and nitrogen stable isotope signatures. Canadian Journal of Zoology 80, 381-387.

Sheridan P. and Hays C. (2003) Are mangroves nursery habitat for transient fishes and decapods? Wetlands 23, 449-458.

Swemmer R. (2011) Ecological integrity assessment at Mvot Estuary Kwazulu-Natal, South-Africa. PhD thesis. University of Johannesburg, South Africa.

Taylor M., Ravilious C. and Green E. (2003) Mangroves of East Africa. UNEP-WCMC Biodiversity Series 13.

Tomlinson P.B. (1986) The botany of mangroves. Cambridge: Cambridge University Press.

Valiela I., Bowen J.L. and York J.K. (2001) Mangrove forests: one of the world's threatened major tropical environments. BioScience 51, $807-815$.
Wakwabi E.O. (1999) The ichthyofauna of a tropical mangrove bay (Gazi Bay, Kenya): community structure and trophic organisation. $\mathrm{PhD}$ thesis. University of Ghent, Belgium.

Wakwabi E.O. and Mees J. (1999) The epibenthos of the backwaters of a tropical mangrove Creek (Tudor Creek, Mombasa, Kenya). Netherlands Journal of Zoology 49, 189-206.

and

Whitfield A.K. (1998) Fish conservation in South African estuaries. Aquatic Conservation: Marine and Freshwater Ecosystems 7, 1-11.

\section{Correspondence should be addressed to}

L. Gajdzik

Laboratory of Functional and Evolutionary Morphology University of Liège, Allée de la chimie 3, B6c, B-40oo Liège Belgium

email: 1.gajdzik@student.ulg.ac.be 